\section{US response to Sellafield data}

\section{Washington}

THE startling suggestion in a recent UK study that low-level radiation doses to men may cause genetic defects in their children has sparked a flurry of calls for independent verification in the United States. First results of a US study could be out early this summer.

A team led by Martin Gardner of the University of Southampton last month released results showing that children whose fathers worked at the Sellafield nuclear waste reprocessing plant were seven or eight times more likely to develop leukaemia if their fathers had received a total radiation dose of 100 millisieverts, or over $10 \mathrm{mSv}$ in the six months before conception (Nature 343, 679; 22 February 1990). A similar study, with results due out in June, is being conducted by John Boice of the US National Cancer Institute (NCI). Boice and his colleagues surveyed cancer deaths in 113 counties containing or adjacent to 61 US nuclear facilities. All 52 commercial nuclear power facilities that started operation before 1982 are included, as are nine Department of Energy (DOE) facilities.

The nationwide study was begun in 1987 because of general public health concern, amplified by a British survey of cancer deaths near UK nuclear facilities that showed 'clusters' of childhood leukaemia (Nature 329, 499; 1987). DOE facilities were included in the NCI survey because they are similar to the UK nuclear plants.

Although the US study concentrates on children living near nuclear plants, whether their fathers work at the facilities or not, further analysis of the data by parental occupation should be able to reveal a 'Sellafield effect'. Boice will not comment on the UK study or his team's results until the NCI study is released.

Elsewhere in the United States, the Sellafield study is expected to prompt new research into the possibility of inherited genetic damage.

A special session at the American Statistical Association's August meeting in Anaheim, California will discuss the Sellafield results and how best to assess the effects of low-dose radiation.

US researchers say the Sellafield results, if confirmed, are surprising enough to change dramatically the science of radiation epidemiology. "The fact that the radiation exposure to fathers [in the study] was within guidelines, and that those [small] doses are capable of making changes in the reproductive cells is biologically difficult to explain", says Shirley Fry, an epidemiologist at Oak Ridge Associated Universities, who is studying workers at DOE facilities. Although "the reaction has been substantial on this side of the Atlantic", says Daniel Hoffman, assistant director of the Center of Environmental Health at the Centers for Disease Control in Atlanta, "the main thing now is to get replication with the large cohort of DOE and [US] nuclear plant workers". He says that although there have been weak associations between childhood leukaemia and paternal radiation doses in previous US surveys, the Sellafield study is the first to make a convincing case.

The Sellafield study, however, comes at an awkward time for the DOE epidemiology programme. In an interim report submitted last week, a DOE advisory panel recommended that much of the agency's research into the health effects of radiation exposure should be transferred to other agencies to avoid the widespread perception of conflict of interest (see Nature 344, 92; 8 March 1990). Although the panel has also called for increased funding for epidemiological research at the agency, director Robert Goldsmith says "it is not clear what is going to happen" to the programme.

G. Christopher Anderson

- Reports from India allege that leukaemia clusters have been found near nuclear installations, page 185 .

\section{London}

A REPORT published last week suggests that many workers in non-nuclear heavy industries may have "potential problems" similar to those caused by radiation exposure in the nuclear industry. The suggestion, from Professor Murdoch Baxter and colleagues at the Scottish Universities Research and Reactor Centre, has been widely publicized in the wake of the Gardner report, which linked childhood leukaemia near the Sellafield nuclear reprocessing plant to fathers' radiation exposure (Nature 343, 679, 1990).

But the British government's radiation watchdog, the National Radiological Protection Board (NRPB), has rejected Baxter's conclusions.

Baxter was commissioned by the East Yorkshire Health Authority to investigate the possibility of a link between a cluster of childhood cancers on Humberside and discharges of radioactive polonium from the Capper Pass tin-smelting plant. Baxter found no evidence that radioactive discharges are to blame, but his report says nevertheless that the concentrations of a number of radioactive nuclides in the ore processed at the plant are potentially hazardous. Working practices at Capper Pass and elsewhere "should be brought into line with those which apply through-

\section{Decline in R\&D expenditure}

\section{Cape Town}

EXPENDITURE on research and development in South Africa declined from 0.96 per cent of gross domestic product in $1985-86$, to 0.88 per cent (R1,329 million) in 1987-88, according to a report from the Department of National Education. The private sector share of spending has remained almost constant over the two-year period at 41.3 per cent but has declined since 1983 when it stood at 51.2 per cent.

The tertiary education sector receives 25.5 per cent of total research and development funds, considerably more than in most OECD (Organization for Economic Cooperation and Development) countries and indicating the sector's crucial role in South Africa's economic development. Universities receive $\mathbf{9 8 . 2}$ per cent of these funds, with the University of Pretoria receiving the highest proportion (14.6 per cent), followed closely by the University of Cape Town (14.5 per cent).

Of government spending, a massive 26 per cent goes to agriculture against two per cent for the United States and West Germany. As a matter of policy, the report does not indicate the percentage of funds going to military research and development.

\title{
More radiation hazards
}

out the nuclear industry", the report concludes.

John Hipkin, from NRPB's office in Leeds, agrees that there is some radioactivity in the ore. But radiation doses received, he says, depend on the dustiness of the atmosphere in the plant and the timing of workers' exposure. NRPB already monitors working practices at Capper Pass and similar sites, Hipkin says, and where there are problems, ventilation is improved or workers wear dust masks. Hipkin charges that Baxter's reference to Gardner's findings is "completely irrelevant" because radiation doses in Capper Pass are many times less than those that were measured at Sellafield. Michael Snee, a radiotherapist who was an author of the Gardner report, agrees that very few workers outside the nuclear industry receive radiation doses comparable to the Sellafield levels, but thinks may be some exceptional cases, such as industrial radiographers who use radioisotopes to trace leaks in metal pipes.

Peter Aldhous

Correction: The 22 February news story about the Gardner report stated incorrectly that the nuclear reprocessing plant at Dounreay is operated by British Nuclear Fuels. In fact the site operators are the UK Atomic Energy Authority. 